CURRENT RESEARCH JOURNAL OF PHILOLOGICAL SCIENCES

(ISSN -2767-3758)

VOLUME 03 ISSUE 01 Pages: 58-63

SJIF IMPACT FACTOR (2021: 5.823 )

OCLC - 1242423883 METADATA IF - 6.925

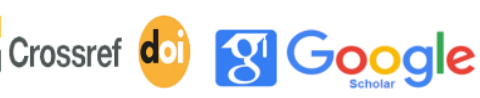

10

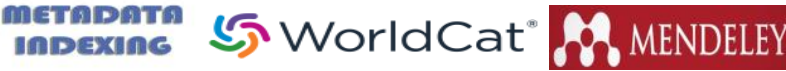

Publisher: Master Journals

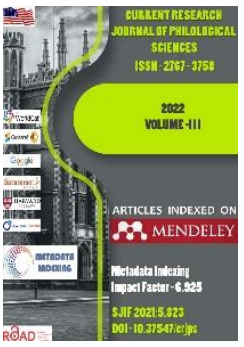

Journal Website: https://masterjournals. com/index.php/crips

Copyright: Original content from this work may be used under the terms of the creative commons attributes 4.0 licence.
Research Article

\section{THE STUDIES OF RELIEF NOUNS BY UZBEK LINGUISTS}

Submission Date: January 07, 2022, Accepted Date: January 17, 2022, Published Date: January 27, 2022

Crossref doi: https://doi.org/10.37547/philological-crjps-03-01-10

\section{Bekzod B. Farmonov}

Tashkent State University of Uzbek Language and Literature named after Alisher Navoiy, Uzbekistan

\title{
ABSTRACT
}

This article provides detailed information about the derivatives of nouns from the word relief in the Uzbek language, about their study and classification in Uzbek linguistics. A classification of linguistic studies of relief nouns in the Uzbek language is proposed. Also, special attention is paid to the importance of studying the semantic structure, historical and etymological features, theoretical and practical issues related to the lexical interpretation of relief nouns in the Uzbek language.

\section{KEYWORDS}

Language, lexical layer, relief, mountain, general lexical unity, earth layer, upland, plain, lowland, philological dictionary, encyclopedic dictionary, translation dictionary.

\section{INTRODUCTION}

Language as a reflection of being is a complex social phenomenon that embodies all natural and social phenomena. The events of reality are different. Each of them has its own separate natural and social peculiarity, task and significance. For this purpose, each of the harmonic phenomena requires its own specific name, purpose. The lexical units of the language are also diverse and colorful, like all phenomena, forms and meanings characteristic of different traditions, values, culture, moods, things and 
CURRENT RESEARCH JOURNAL OF PHILOLOGICAL SCIENCES

(ISSN -2767-3758)

VOLUME 03 ISSUE 01 Pages: 58-63

SJIF IMPACT FACTOR (2021: 5. 823)

OCLC - 1242423883 METADATA IF - 6.925

Crossref
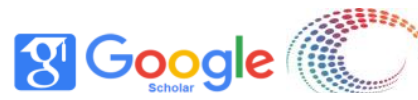

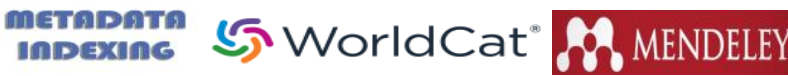

Publisher: Master Journals

phenomena, concepts related to science, technology, art, life, etc. One of such phenomena is the various forms and appearance of the earth's surface, and words in their qualitative expression in language have the same varied form and meaning as the very appearance of the earth's surface. In each language, the lexical units representing the terrain are formed in its own way. In particular, words and terms such as tog', adir, jar, o'r, tekislik, pastlik, qir, chuqur, dovon, yonbag'ir, cho'qqi associated with the concepts of the terrain, occupy a special place in the lexicon of the Uzbek language. Such lexical units as these are fixed at the expense of their own and other linguistic units as a group of words - relief nouns representing concepts related to the relief of the earth's surface, and also, along with the formation of a separate group of lexemes in the lexical system of the language, serve as an important resource in the formation and development systems of words - relief nouns. A number of scientific studies were carried out on similar lexical units of the Uzbek language and vocabularysemantic groups, as a result of which theoretical and practical achievements in the lexicology of the Uzbek language were obtained. In the field of studying the vocabulary of the Uzbek language, the scientific research of the following linguists should be separately noted: A. Gulomov, S. Ibrokhimov, A. Rustamov, A. Khozhiev, Sh. Rakhmatullaev, U. Tursunov, X. Doniyorov, 3. Marupov, E. Begmatov, H. Nematov, I. Kuchkortoev, Olim Usmon, T. Aligulov, B. Urinboev, R. Kungirov, E. Umarov, B. Bafoev, H. Dadaboev, R. Rasulov, R. Doniyorov, N. Makhkamov, A. Madvaliev , A. Sobirov. And the systemic and structural interpretation of the vocabulary of the Uzbek language was carried out in the studies of a number of linguists, such as Sh. Rakhmatullaev, I. Kucheortoev, A. Nurmonov, Kh. Nematov, M. Mirtozhiev, N. Makhmudov, R. Rasulov, O. Bozorov, R. Safarova, Sh.
Iskandarova, Z. Yunusova, M. Narzieva, Sh. Orifjonova, B. Kilichev, G. Nematova, Kh. Saidova, Nishonova.

The composition of the lexical levels of the Uzbek language as a result of lexicological studies carried out by consanguinity, names of plants, animals, quantitysize, wind-precipitation, clothing, relief names, units of names, etc., which are studied as microsystems, have received greater clarity of meaning and functions vocabulary units, role in the system of lexical units.

${ }^{1}$ Rahmatullayev Sh. Sememe - an independent language unit // Journal of the Uzbek language and literature.1984. 5-n ; Quchqortoyev I. The meaning of the word and its valence. - Tashkent: SCIENCE, 1977; Begmatov E., Nematov H., Rasulov R. Lexical microsystem and its research methods (Systems lexicology theses) // Journal of Uzbek language and literature.1989. 6-n. - pages. 35- 40; Rasulov R. Situational verbs in Uzbek language and their obligatory valences. - Tashkent: SCIENCE, 1989; Safarova R.G. Hyponymy in the Uzbek language (on the material of common consumer zoonymes): PhD. Tashkent, 1990; Nematov H., Rasulov R. Fundamentals of Uzbek language system lexicology. -Tashkent: Teacher, 1995; Bozorov O. Leveling in the Uzbek language: PhD. - Tashkent, 1997; Iskandarova Sh. Study of Uzbek lexicon as a semantic field (personal microfield): PhD. - Tashkent.

The theoretical and practical significance of the conclusions and recommendations of such a study are also considered especially important, since they serve as models of modern dictionaries and an important 


\section{CURRENT RESEARCH JOURNAL OF PHILOLOGICAL SCIENCES}

(ISSN -2767-3758)

VOLUME 03 ISSUE 01 Pages: 58-63

SJIF IMPACT FACTOR (2021: 5. 823)

OCLC - 1242423883 METADATA IF - 6.925

Crossref
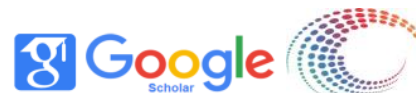

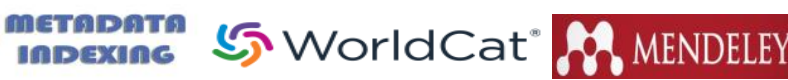

Publisher: Master Journals

source, material for translation dictionaries. And this determines the relevance of lexico-semasiological research on each lexical microsystem in the lexical system of vocabulary-semantic groups. The relief of the earth's surface in Uzbekistan is mainly represented by land, therefore, the nouns of the reliefs in the Uzbek language, respectively, serve to express the concepts of lowlands, hills, associated mainly with the level of the earth. Therefore, the system of units of the Uzbek language representing the relief of the earth's surface and its composition is formed in a special way. Therefore, the lexical units that represent various forms and types of the earth's surface, we consider it expedient to combine relief nouns under a common name. All relief nouns are based on the meaning of relief nouns. In this regard, we considered it necessary to pay attention to the lexicographic interpretation and interpretation of the linguistic unit of relief in order to create a more vivid picture of the relief nouns and their lexical essence. The lexical unit relief has its own word forms as a geographical term with its lexical interpretation and description in general philological and special terminological dictionaries. This unit, referring to the borrowed layer of the

1999; Orifjonova Sh. Lexical graduonymy in Uzbek language: Philosophy. of doc. on philology. -Tashkent. 1996; Yunusova Z. The structure and development of the lexical microsystem in the Uzbek language: Phil. of doc. on philology - Tashkent, 2004;

Safarova R.G. Hyponymy in the Uzbek language (on the material of common consumer zoonymes): PhD. Tashkent, 1990; Iskandarova Sh. Study of Uzbek lexicon as a semantic field (personal microfield): Phil. of doc. on philology. -Tashkent. 1999; Qilichev B. Partonymy in Uzbek language: Philosophy. of doc. on philology. -Tashkent, 1997; Nematova G. Lexemes of plant names in Uzbek language: system and artistic use: Philosophy. of doc. on philology. -Tashkent, 1998; Narzieva M. Component analysis of relationship names // Uzbek language and literature. - Tashkent,1986. - № 5. - pages. 15-17; Nishonova N. Semantic analysis of the field of archetypal lexemes "animal" in the Uzbek language: Philosophy. of doc. on philology. -Tashkent, 2000; Saidova X. Use of animal names in Uzbek as a personal description: Philosophy. of doc. on philology - Samarkand, 1995; Aliqulov A. weather names in Uzbek language; Islomov I. The system of nominal units representing the views of the earth's surface in the Uzbek language: Philosophy. of doc. on philology - Karshi, 2019.

vocabulary of the Uzbek language, is characterized in the "Explanatory Dictionary of the Uzbek Language" as a representative of a geographical concept: ("RELIEF I [French relief <lot. Relevo - rise] geogr. Contain lots of ups and downs, mountainous areas. Mountain relief. The structure of the relief of Uzbekistan is diverse. The topography of the Tashkent land was formed at the same stage. "Science and life") "RELIEF I [french. "relief" lot. "relevo" - (a little) rise] geog. All kinds of irregularities formed naturally or artificially irregularities on the surface of the earth - lowlands hills, burn flat. Mountainous relief. The relief structure of Uzbekistan is diverse. - The appearance of the soil of Tashkent, that is, its relief, was formed at the same stage. "Science and life". The lexical unit of relief also has a terminological interpretation, as an expression of the concept in the sphere of geographical terminology: "Relief" - (from the French. Relief - I raise) - forms of the earth's surface: mountains, plains, lowlands, hilly terrain, plateaus, hills, hilly steppes, valleys, depressions, hollows, ravines and other aggregates. The relief is formed as a result of the simultaneous constant impact on the earth's surface of two forces - 
CURRENT RESEARCH JOURNAL OF PHILOLOGICAL SCIENCES

(ISSN -2767-3758)

VOLUME 03 ISSUE 01 Pages: 58-63

SJIF IMPACT FACTOR (2021: 5. 823)

OCLC - 1242423883 METADATA IF - 6.925

Crossref

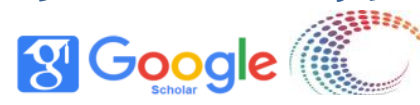
metapata (5) WorldCat I $^{\circ}$ MENDELEY

Publisher: Master Journals

endogenous (internal) and exogenous (external) processes (Relief of two forces - the result of the joint and regular interaction of internal (endogenous) and external (exogenous) forces "). And in encyclopedic dictionaries this concept is also characterized, expressed through the following lexical unit: "Relief (lat. Relevo - I raise) in geography is the surface of the earth, a set of irregularities of the land surface, the bottom of the oceans and seas. There are the following types of relief:

- Mega-relief (continental ledges, ocean floor);

- Macrorelief (mountain ranges, hills, lowlands);

- Mesorelief (ravines, underwater canyons, hills);

- Microrelief (small ravines, sandy hills)".

1 Annotated dictionary of the Uzbek language. $V$ volume. - Tashkent: National Encyclopedia of Uzbekistan, 2007. - Volume 3. - 688 page.

Based on the above lexical interpretations, which are expressions in the language, the concept of relief and its reflection in the names of reliefs becomes clearer. The various aspects reflected in the lexicographic interpretations and descriptions associated with the concept of relief are essentially related to the characterization of one phenomenon with a different aspect point of view. Basically, the lexical unit of relief is presented as a term expressing various types of the earth's surface. From this it becomes clear that for the Uzbek language the lexical unit relief occupies an important place as a term of sectoral meaning, which, denoting a set of different types and forms of the earth's surface, mainly land, performs a dominant function in relation to linguistic units that represent all forms and types. the earth's surface. And this indicates that the lexical unit relief is in the status of a hyperonym, uniting all the nouns of reliefs - relief nouns - into a single system. Among the presented lexicographic interpretations, the most important is the philological interpretation, because in the vocabulary of the language, a common feature is of decisive importance. On this basis, encyclopedic and sectoral interpretations are formed. As scientific research carried out on the study of relief nouns in the Uzbek language, one can mention the research works of K. Khurramov and I. Islomov. In the 80 s of the last century, the linguist $\mathrm{V}$. Khurramov studied the nouns of the terrain in terms of general geographic terms. This study is the first research work carried out on the names of reliefs in the Uzbek language. In it, as a source of research, national geographical terms of southern Uzbekistan and dialectal units representing land reliefs were selected, which were analyzed by dividing them into groups of types of land reliefs "geographical terms denoting hills" and "geographical terms denoting lowlands". V. Khurramov's monograph, devoted to the study of the terms of the relief of the earth, is of a dialectal nature, however, "... to some extent does not correspond to the requirements of lexicography."

${ }^{1}$ Gulomov P. An explanatory dictionary of geographical terms and concepts. - Tashkent: Teacher, 1994. - 144 page.

${ }^{1}$ National Encyclopedia of Uzbekistan. - Tashkent: National Encyclopedia of Uzbekistan. - 2006. - 656 page. 
CURRENT RESEARCH JOURNAL OF PHILOLOGICAL SCIENCES

(ISSN -2767-3758)

VOLUME 03 ISSUE 01 Pages: 58-63

SJIF IMPACT FACTOR (2021: 5. 823)

OCLC - 1242423883 METADATA IF - 6.925

Crossref
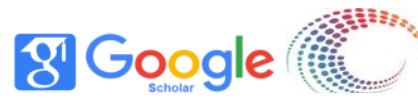

metapata (5) WorldCat I $^{\circ}$ MENDELEY

Publisher: Master Journals

However, the units collected and analyzed by him, pointing to the reliefs of the land, occupy a special place in the formation and development of the structure of specific terms of the lexical system of the Uzbek national language.

In this study, in aspect, the systemic structure of units of nouns, expressing ideas about the surface of the earth, the general meaning of the terrain in the Uzbek language, was studied. The system of lexemes belonging to the general literary vocabulary associated with the concept of relief is defined as a separate lexical-semantic group, differs in that it is analyzed and interpreted by the methods and techniques of systemic linguistics. The presence of the feature "outline of the ground level" in the semantic structure of relief names of the Uzbek language is stated as an integral seme, which performs the function of a connecting "ring" of relief nouns in the system of relief nouns, is classified on the basis of the semes "outlines above ground level”, "outlines below ground level”, “ outlines equal to the ground level ", which represent the semantic structure of the relief lexemes:

1) A group of ETSIH, expressing elevation;

2) A group of ETSIH, expressing the plain;

\section{3) A group of ETSIH, expressing lowland.}

(EETVOZ - the unity of terms expressing the outlines of the earth's surface)

Also in this study, in order to clarify the linguistic nature of lexemes, determine the commonality and difference between units of other related areas, the issue of their relationship with geographical terms, dialectal units, and toponyms was analyzed. Also, the issues of lexical and semantic relationships of relief names, historical and etymological affiliation, lexical interpretation, composition and structure of the noun relief system were reflected. In particular, "the historical and etymological layer of the ETVOPZ system in the Uzbek language can be classified

${ }^{1}$ Khurramov K. Uzbek folk geographic terms denoting the relief of Southern Uzbekistan: Author's abstract. dis ... cand. philol. sciences. - Tashkent, 1984.

7 Ishaev A. Uzbek dialectal lexicography. -Tashkent: SCIENCE, 1990. -page. 56.

as follows:

1) Uzbek words; 2) Persian words; 3) Arabic words; 4) Russian words and words of other languages. " In the above classification, words of the type "tog', qir, qoya, bet, do'ng, tepa, cho'qqi, chuqurlik, enba kabir” kabilar are noted as their own layer of words; as Persian words such as "dara, darband, domana, past, heat, biyobon, yovon, dasht, ko'h, kamar, tangi, maydon" borrowings from the Arabic language such words as "sahro, sohil, havza, voha, vodiy". Russian words and borrowed as lexemes through the Russian language "terrace, savannah, crater, plateau, delta". Based on the foregoing, it is necessary to divide the linguistic study of relief nouns in the Uzbek language into two stages:

1) The study of relief nouns in the dialectal aspect;

2) The study of relief nouns in the systemic and structural aspect.

As a result of the study carried out on relief names in the Uzbek language, their dialectal, terminological, common meanings were highlighted, their general and distinctive aspects were clarified. Also, the possibility of improving the lexicographic interpretation of relief 
CURRENT RESEARCH JOURNAL OF PHILOLOGICAL SCIENCES

(ISSN -2767-3758)

VOLUME 03 ISSUE 01 Pages: 58-63

SJIF IMPACT FACTOR (2021: 5.823 )

OCLC - 1242423883 METADATA IF - 6.925

Crossref doi 81 Google (2)

5. National Encyclopedia of Uzbekistan. -

Tashkent: National Encyclopedia of

Uzbekistan. - 2006. - 656 page.

CONCLUSION

In general, the issue of a comparative study of the dialects of the common Uzbek language with nouns in relief in other languages requires further scientific research.

And this contributes to the determination of the linguistic value of relief names, the identification of common and distinctive features characteristic of the semantic structure of relief nouns belonging to the vocabulary of different languages, serves to improve their lexical interpretations.

${ }^{1}$ Islomov I. The system of nomenclature in the Uzbek language: doctor of phylosophy on phylology. - Karshi, 2019.

${ }^{1}$ That page: 86 -page.

\section{REFERENCES}

1. Ishaev A. Uzbek dialectal lexicography. Tashkent: SCIENCE, 1990. - 140 page.

2. Islomov I. The system of nomenclature in the Uzbek language: doctor of phylosophy on phylology. - Karshi, 2019. - 125 page.

3. 5. Khurramov K. Uzbek folk geographic terms denoting the relief of Southern Uzbekistan: Author. dis ... cand. philol. sciences. - Tashkent, 1984. - 112 page.

4. Annotated dictionary of the Uzbek language. $V$ volume. - Tashkent: National Encyclopedia of Uzbekistan, 2007. - Volume 3. - 688 page. 